\title{
Clinical aspects of human rabies in the state of Ceará, Brazil: an overview of 63 cases
}

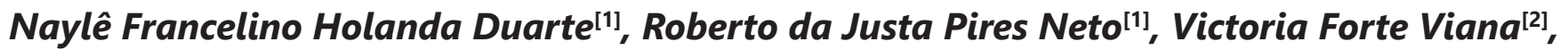 \\ Levi Ximenes Feijãão ${ }^{[3]}$, Carlos Henrique Alencar ${ }^{[1]}$ and Jorg Heukelbach ${ }^{[1]}$
}

[1]. Universidade Federal do Ceará, Faculdade de Medicina, Programa de Pós-Graduação em Saúde Pública, Fortaleza, CE, Brasil.

[2]. Universidade de Fortaleza, Centro de Ciências da Saúde, Fortaleza, CE, Brasil.

[3]. Secretaria da Saúde do Estado do Ceará, Fortaleza, CE, Brasil.

\begin{abstract}
Introduction: Rabies is considered one of the most relevant public health problems owing to its high fatality rate and the high number of deaths worldwide. Methods: We included patients with human rabies who attended a reference hospital in the state of Ceará during 1976-2019. Results: Data were available for 63 out of 171 (36.8\%) patients. Of these patients, $48(76.2 \%)$ were attacked by dogs. In recent years, wild animals have been the most common aggressor species (marmosets and bats). Only 39 (70\%) patients were initially correctly suspected with rabies. Bites were the most frequent exposure $(56 ; 96 \%)$, most commonly on the hands $(21 ; 42 \%)$ and the head $(9 ; 18.4 \%)$. Only $14(22 \%)$ patients had sought medical assistance before the onset of symptoms, and only one completed post-exposure prophylaxis. The most prevalent signs and symptoms included aggressiveness/irritability $(50 ; 79.4 \%)$, fever $(42 ; 66.7 \%)$, sore throat/ dysphagia $(40 ; 63.5 \%)$, and myalgia $(28 ; 44.4 \%)$. Hydrophobia was present in 17 patients $(22.0 \%)$. Conclusions: Most cases of human rabies in Ceará occurred due to the failure to seek medical assistance and/or the failure of the health system in initiating early postexposure prophylaxis. There is a need for specific information and education campaigns focusing on the cycle of sylvatic rabies as well as prevention measures. Health professionals should undergo refresher training courses on the signs and symptoms of rabies and on the specific epidemiological features of the disease in Brazil.
\end{abstract}

Keywords: Rabies. Zoonosis. Epidemiology. Public Health.

\section{INTRODUCTION}

Human rabies (HR) is a zoonotic viral disease that affects the nervous system. It is a vaccine-preventable disease; however, its course is practically irreversible after the onset of signs and symptoms ${ }^{1}$. The disease causes approximately 60,000 human deaths per year worldwide, with the highest number of cases recorded in rural areas in Africa and Asia ${ }^{2,3}$. The main transmitter is the domestic dog (Canis familiaris), which accounts for approximately $99 \%$ of cases worldwide ${ }^{1}$.

In Brazil, a significant reduction in mortality rates due to HR has been achieved in the last 30 years after the implementation

\footnotetext{
Corresponding author: Prof. Jorg Heukelbach.

e-mail: heukelbach@ufc.br

(D) https://orcid.org/0000-0002-7845-5510

Received 6 April 2021

Accepted 14 June 2021
}

of canine vaccination campaigns and the intensification of the provision of post-exposure prophylaxis. Currently, there are only sporadic cases of HR transmitted by $\operatorname{dogs}^{4}$. In the last decade, 9 (23.7\%) of the 38 HR cases registered in Brazil were transmitted by dogs. The other cases were primarily transmitted by hematophagous bats (52.6\%), followed by non-human primates $(10.5 \%)$ and felines $(10.5 \%)^{4}$. In fact, the hematophagous bat (Desmodus rotundus) is the main transmitter of rabies virus to humans in Brazil, and the variant maintained and transmitted by this species is commonly found in human cases where other species, mainly dogs and cats, are aggressors ${ }^{5,6}$.

In the state of Ceará in Northeast Brazil, dogs, hematophagous bats (Desmodus rotundus), and other wild species are responsible for maintaining and transmitting variants of the rabies virus to humans ${ }^{5-7}$. Of the $46 \mathrm{HR}$ cases registered during 1990-2016 in the state, 52\% occurred in Fortaleza, and dogs were the most common transmitters of the virus. The other cases were distributed throughout the state's municipalities, and the virus was transmitted 
by marmosets (Callithrix jacchus) (26\%), bats (8.7\%), and raccoons $(2.2 \%)^{7-10}$. In fact, since 2004 , wild animals, especially marmosets, have become more prominent in the transmission chain in Ceará ${ }^{7-9}$. Recent studies have shown that bats are the main reservoirs for the circulation of the HR virus in Ceará ${ }^{8}$. The last case of HR in the state occurred in 2016; the virus was transmitted through a hematophagous bat bite on a farmer who did not seek medical assistance ${ }^{11}$.

Post-exposure prophylaxis after aggression by a rabid animal is highly effective and prevents disease and death. Early diagnosis and the initiation of post-exposure prophylaxis are essential. However, physicians generally have limited knowledge about signs, symptoms, and prophylaxis ${ }^{12}$. Owing to the complexity of the clinical signs, its sporadic occurrence, and the lack of experience of physicians in treating rabies patients, the diagnosis may be delayed.

This study describes the clinical and epidemiological characteristics of 63 patients affected by human rabies in the state of Ceará over a period of 44 years.

\section{METHODS}

The study was carried out in the state of Ceará in Northeast Brazil (population: 8.8 million, Figure 1). In the state, 171 human

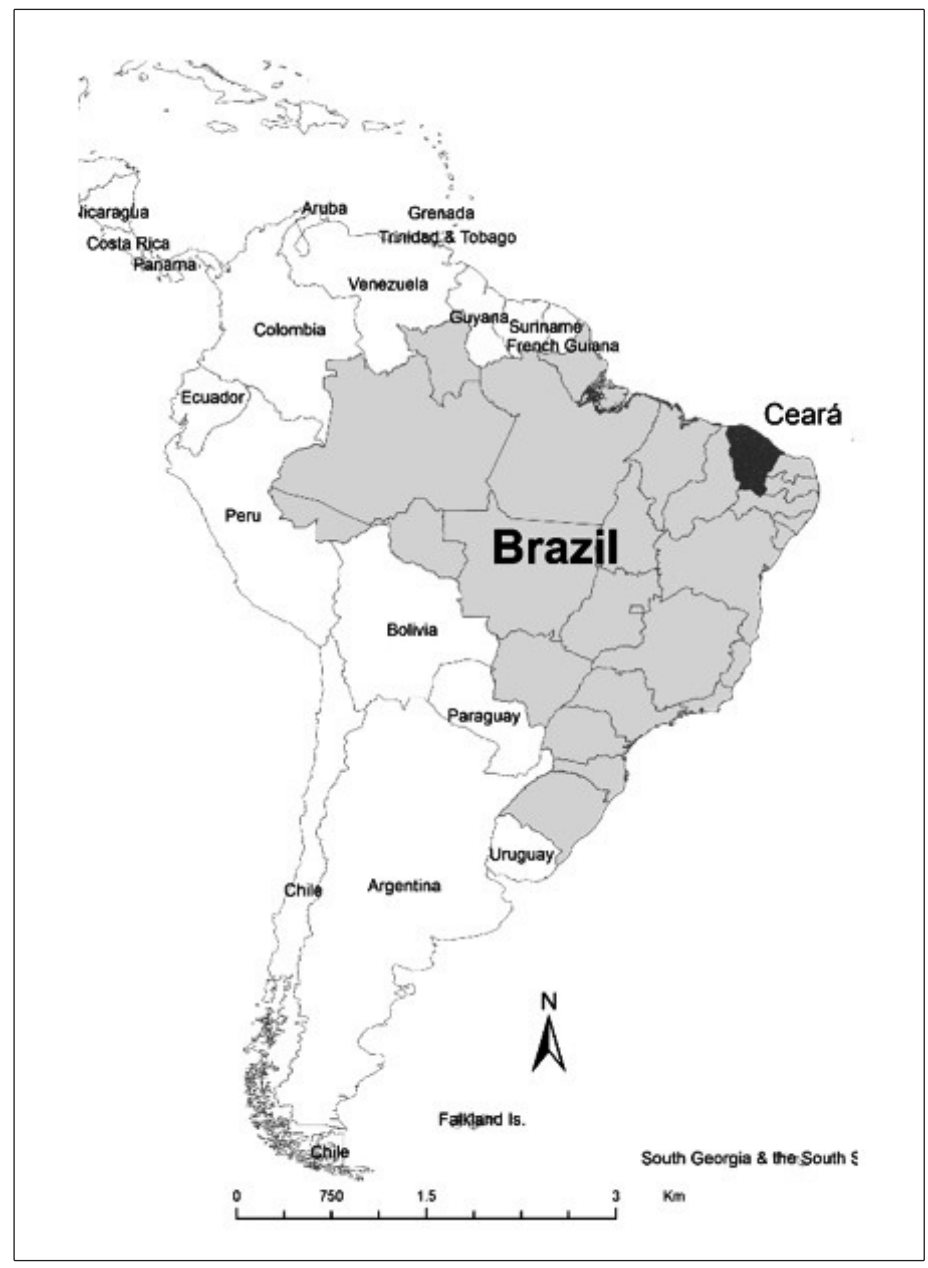

FIGURE 1: Location of the State of Ceará in Northeast Brazil in Latin America. rabies cases were reported during 1970-2019, with a constant decrease in the number of cases since 1978, after the start of intensive animal vaccination campaigns ${ }^{7}$. The last human rabies case transmitted by a dog occurred in 2010 and that transmitted by a sylvatic animal (hematophagous bat, Desmodus rotundus) occurred in 2016.

The target population included all human rabies cases from which data were available in records, that is, from 1976 until the last registered case in 2016 , attended by the state reference hospital for infectious diseases in the state capital Fortaleza (São José Hospital of Infectious Diseases). All registered rabies cases were treated at this hospital, as this is the only reference hospital for infectious diseases in the state. The analysis included all patient charts encountered in the hospital archives.

The variables available and analyzed in this study included epidemiological and clinical data, such as aggressor species, type of aggression/exposure to the virus, location of lesion, post-exposure prophylaxis, origin of the animal, animal situation, follow-up on animal, animal observation, incubation period, signs and symptoms, initial diagnosis, aggression dates, onset of symptoms, and death.

Data entry, processing, and analysis were performed using Microsoft Excel 2010 software within a database. The virus incubation period was calculated as the difference in days between the aggression date and the date of symptom onset. The patients' lifetimes were calculated based on the difference in days between the date of death and the date of the onset of clinical signs.

The study was approved by the Ethical Review Boards of the Federal University of Ceará (CAAE number: 13466719.6.0000.5054), of the State Health Secretariat (CAAE number - 13466719.6.3001.5051), and of the Reference Hospital for Infectious Diseases São José (CAAE number: 13466719.6 .3002.5044).

\section{RESULTS}

Sixty-three patient charts were included in the analysis, representing $36.8 \%$ of the 171 patients who attended the reference hospital during the study period. Table 1 shows the epidemiological characteristics of patients. Approximately $25 \%$ of cases involved dogs as aggressors, and bites were by far the most frequent type of exposure, mostly on the hands (Table 1). Only 14 (22\%) patients sought medical services after the attack (before the onset of specific symptoms). No treatment was prescribed for two of these patients, and the remaining patients received different prescriptions for post-exposure prophylaxis with a variation of 1 to 13 doses of rabies vaccine. Of these patients, nine (75\%) did not complete the treatment. The origin of the aggressor animal was available only in $33(52.3 \%)$ medical records, with approximately one-third (36.4\%) being stray dogs.

The most prevalent signs and symptoms included changes in behavior (aggressiveness/irritability), followed by fever and pain in the throat/dysphagia (Table 2). Hydrophobia was common. Therapy was based on antibiotics, antivirals, anticonvulsants, analgesics, and antipyretics. The four cases of human rabies that occurred since 2010 were submitted to the so-called Recife protocol, but none of them survived. 
TABLE 1: Characteristics of human rabies cases according to the aggressor animal species, exposure type, injury site, post-exposure prophylaxis, animal origin, animal condition, and animal monitoring ( $\mathrm{N}=63)$, Ceará, Brazil, 1976-2019.

\begin{tabular}{|c|c|c|}
\hline Variable & Number & $\%$ \\
\hline \multicolumn{3}{|l|}{ Aggressor animal species } \\
\hline Dog & 48 & 76.2 \\
\hline Marmoset & 6 & 9.5 \\
\hline Hematophagous bat & 5 & 7.9 \\
\hline Unknown & 3 & 4.8 \\
\hline Cat & 1 & 1.6 \\
\hline \multicolumn{3}{|l|}{ Exposure type* } \\
\hline Bite & 56 & 96.6 \\
\hline Scratch & 2 & 3.4 \\
\hline \multicolumn{3}{|l|}{ Lesion location* } \\
\hline Hand & 21 & 42.9 \\
\hline Head & 9 & 18.4 \\
\hline Upper limbs & 5 & 10.2 \\
\hline Lower limbs & 5 & 10.2 \\
\hline Foot & 3 & 6.1 \\
\hline Trunk & 3 & 6.1 \\
\hline Head + upper limb & 2 & 4.1 \\
\hline Hand + upper limb & 1 & 2.0 \\
\hline \multicolumn{3}{|l|}{ Post-exposure prophylaxis } \\
\hline Did not seek assistance & 49 & 77.8 \\
\hline 13 doses of anti-rabies serum & 3 & 4.8 \\
\hline 1 dose of vaccine & 3 & 4.8 \\
\hline No treatment recommendation & 2 & 3.2 \\
\hline 3 doses of vaccine & 2 & 3.2 \\
\hline 11 doses of vaccine & 1 & 1.6 \\
\hline Completed treatment & 1 & 1.6 \\
\hline 10 doses of vaccine + antiserum + booster every 10 days & 1 & 1.6 \\
\hline 7 doses of vaccine & 1 & 1.6 \\
\hline \multicolumn{3}{|l|}{ Animal origin* } \\
\hline Stray dog & 12 & 36.4 \\
\hline Domestic & 11 & 33.3 \\
\hline Wild & 10 & 30.3 \\
\hline \multicolumn{3}{|l|}{ Animal condition* } \\
\hline Abnormal behavior & 35 & 85.4 \\
\hline No symptoms at the time of aggression & 5 & 12.2 \\
\hline Unknown & 1 & 2.4 \\
\hline \multicolumn{3}{|l|}{ Follow-up on animal* } \\
\hline Dead & 26 & 63.4 \\
\hline Disappeared & 11 & 26.8 \\
\hline Unknown & 4 & 9.7 \\
\hline
\end{tabular}

* Data not available for all cases (see Materials and Methods).

Only 39 (70\%) of the patients had an initial diagnosis of rabies when they sought the health unit after presenting the clinical signs of the disease; the other cases were first diagnosed as acute encephalitis $(4 ; 7.1 \%)$ and meningitis $(3 ; 5.4 \%)$, followed by a single diagnosis of respiratory infection, poliomyelitis, acute abdomen, acute polyencephalitis, pneumonia, nervousness/pneumonia/meningitis/ rabies, head trauma, intestinal obstruction, dengue/meningitis, and Guillain-Barré syndrome.

The mean time of the incubation period, in days, for patients being attacked by dogs was 49.2 (amplitude: 13-149), by marmosets 44.8 (20-61), by hematophagous bats Desmodus rotundus 33.5 (14-68), and for the patient being bitten by a cat, it was 118 days.
In general, dogs were the main transmitters, with six and seven cases in 1979 and 1980, followed by six cases in 1982 and 2003, respectively. Six cases transmitted by marmosets were recorded in 1980, 1981, 1991, 2008, 2010, and 2012. Of the five cases transmitted by bats, two occurred in 1985, and single cases occurred in 1983, 1995, and 2016. A single case transmitted by a cat occurred in 1979 (Figure 2).

The mean lifespan of patients after being attacked by dogs and cats was 5.8 and 3.0 days, respectively. After the attack by marmosets and bats, the mean lifespan was 9.7 and 9.4 days, respectively. 
TABLE 2: Signs and symptoms of rabies patients ( $\mathrm{N}=63)$, Ceará, Brazil. 1976-2019.

\begin{tabular}{|c|c|c|}
\hline Signs and symptoms & Number & $\%$ \\
\hline Behavior change (aggressiveness/irritability) & 50 & 79.4 \\
\hline Fever & 42 & 66.7 \\
\hline Sore throat/Dysphagia & 40 & 63.5 \\
\hline Myalgia & 28 & 44.4 \\
\hline Paresthesia & 22 & 34.9 \\
\hline Hydrophobia & 17 & 27.0 \\
\hline Headache & 17 & 27.0 \\
\hline Sensitivity to drafts & 16 & 25.4 \\
\hline Tremor & 15 & 23.8 \\
\hline Insomnia & 14 & 22.2 \\
\hline Inability to walk & 14 & 22.2 \\
\hline Anorexia & 13 & 20.6 \\
\hline Nausea/Vomiting & 11 & 17.5 \\
\hline Prostration & 11 & 17.5 \\
\hline Shortness of breath & 11 & 17.5 \\
\hline Dysarthria (speech disorder) & 10 & 15.9 \\
\hline Sweating & 7 & 11.1 \\
\hline Hoarse cough & 6 & 9.5 \\
\hline Seizures & 6 & 9.5 \\
\hline Photophobia & 3 & 4.8 \\
\hline Difficulty in urination and evacuation & 2 & 3.2 \\
\hline
\end{tabular}

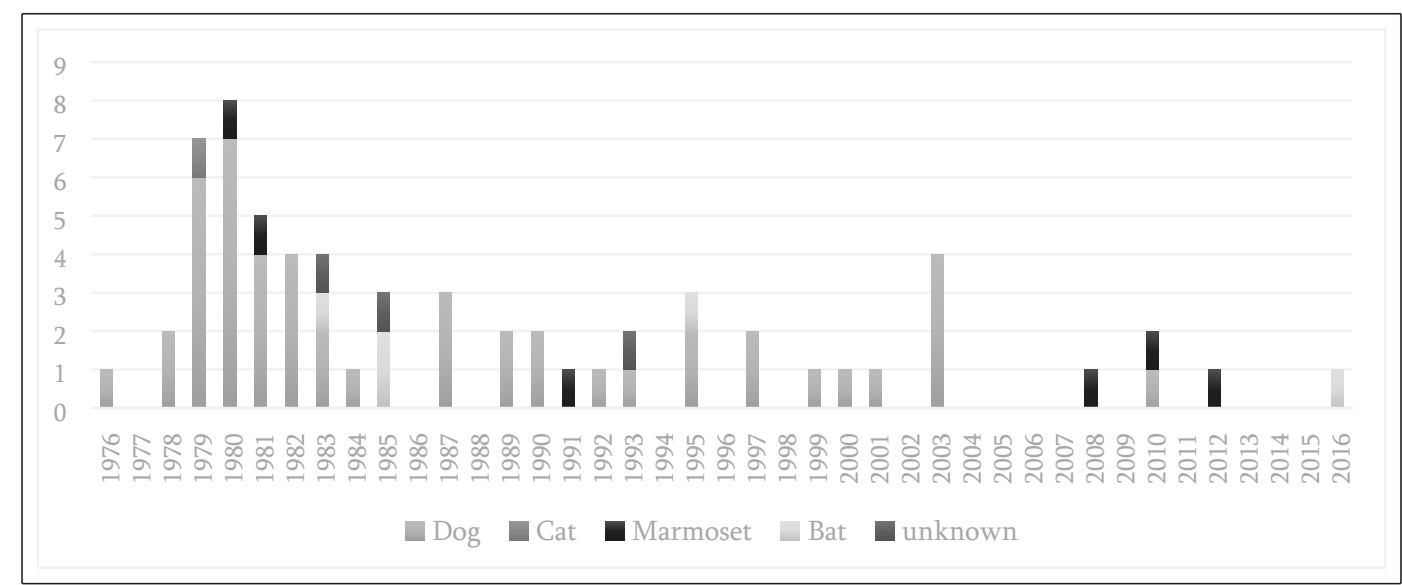

FIGURE 2: Human rabies cases by year of occurrence and aggressor animal species $(\mathrm{N}=63)$, Ceará, Brazil, during 1976-2016.

\section{DISCUSSION}

This is the first systematic study on the epidemiological and clinical characteristics of human rabies in the state of Ceará, covering a 44-year period. In the first few years, dogs were the main transmitters of the virus and were responsible for $75 \%$ of all cases. In recent years, wild animals have become the most important aggressor species. Most victims were not aware of the importance and necessity of seeking assistance after being attacked. Hands were the most common body parts affected through bites. Health professionals often failed to diagnose rabies and did not prescribe post-exposure prophylaxis over time.

The clinical signs presented were mostly related to behavioral changes, such as aggressiveness and irritability, but the initial diagnosis of the disease was dismissed in $30 \%$ of cases. This reinforces the importance of assessing any mammal exposure and suspecting human rabies whenever a patient is seen in the health care system with a sudden onset of neurological symptoms. During an outbreak of human rabies in the state of Amazonas in Brazil, most victims presented similar neurological disorders such as paraparesis $(87.5 \%)$, aggression and/or agitation $(37.5 \%)$, mental confusion $(25 \%)$, and tetraparesis $(18.8 \%)^{13}$. In another study in Brazil, patients presented with fever (92.6\%), agitation (85.2\%), paresthesia (66.7\%), and dysphagia/paralysis $(51.9 \%)^{14}$.

A single patient was attacked by a cat with a longer incubation period, presenting a 118-day interval that does not match the rabies incubation period commonly observed in human beings, which is, on average, 45 days ${ }^{15}$. Nevertheless, the incubation period can vary from days to years, depending on the location, severity, and depth of the lesion and the distance from the wound site to the brain and nerve trunks, the amount of virus inoculated, and the 
viral strain ${ }^{15}$. In a human rabies outbreak in the state of Amazonas due to attacks by hematophagous bats, 15 patients presented an incubation period of 16 to 39 days, but in one case, it took 120 days until the manifestation of clinical signs ${ }^{13}$. In Brazil, human rabies cases reported from 2007 to 2017 had a median incubation time of 50 days $^{14}$. All these periods are sufficient to seek medical assistance and to initiate postexpouse prophylaxis, preventing the development of the disease and further deaths.

The lifespan of patients counting from the onset of clinical signs until death was within the period of 10 days, consistent with the lifetime of a patient affected by rabies described in the Brazilian Health Surveillance Guide ${ }^{15}$. In the state of Amazonas during the outbreak of cases transmitted by bats, deaths occurred between two and nine days after the onset of symptoms ${ }^{13}$.

Despite attempts to cure the last four patients since 2010 in the state of Ceará, none has had a successful response. The affected patients were mostly treated with antibiotics and antivirals. After the onset of clinical signs, the chances of survival are remote and evidence was restricted to a few case reports ${ }^{16}$. Treatment is based on the Milwaukee/Recife protocol and is recommended for any patients with clinical suspicion of rabies who have an epidemiological link and inadequate post-exposure prophylaxis. The patients must be promptly isolated and admitted to the intensive care unit, providing central venous access, delayed bladder catheterization, and nasoenteral catheterization ${ }^{12}$. Of the 93 patients who received the Milwaukee protocol worldwide so far, 18 survived the disease. Countries with the largest number of survivors included India (five cases), the United States (three cases), and Brazil (two cases). The recovered patients had mild to severe sequelae, with the exception of three cases in the United States who had only mild sequelae ${ }^{17}$.

Dogs, especially stray dogs, are the most common aggressor species in many settings ${ }^{14,18-20}$. This is a consequence of the lack of public policies related to the control of stray dog populations and the fact that pet dogs have the closest relationship with humans. In fact, the control of stray dogs has been considered a priority for the prevention and control of human rabies ${ }^{21,22}$. At the beginning of the study period, the National Rabies Prophylaxis Program (Programa Nacional de Profilaxia para a Raiva - PNPR), based on mass vaccination campaigns of dogs and cats, an action that is considered of great importance for the control of the disease in the country, has not yet been established in the state of Ceará. Implementation started in 1973, with roll-out in all Brazilian states during the four years thereafter ${ }^{23}$. This explains the early period from 1979 to 1980 , with the highest records of human rabies cases due to aggression by dogs found in our study. One third of the dogs that were attacked were stray dogs and had clinical characteristics typical of rabies.

The cases involving wild mammals in this study have been reported since the 1980s. In particular, marmosets are responsible for transmitting the rabies virus to humans. In Ceará, it is common for the rural population to capture and raise non-human primates, such as pets, including marmosets. Because these rural populations are usually unaware of the rabies virus transmission cycle, they do not seek medical assistance after being attacked by a wild animal.
In fact, the marmoset (Callithrix jacchus) has been the main transmitter of the rabies virus to humans in recent years in Ceará. It harbors a unique and exclusive variant, identified for the first time in Ceará, and thus far, this variant has been restricted to Northeast Brazil. Marmosets are the only terrestrial wild species responsible for human cases through direct aggression in the country ${ }^{7,10,35}$. Antigenic analysis and genetic sequencing of the rabies virus in wild and domestic animal species in Ceará allow a better understanding of the dynamics of disease transmission, to improve surveillance and control actions, consequently with the non-occurrence of new cases, serving as an example for Brazil and worldwide ${ }^{5-9}$.

The last record of a rabies case transmitted by a marmoset was in 2012 in a rural setting. The state rabies control program subsequently implemented measures to reduce the risk of rabies transmitted by wild animals, by actions such as the provision of information and education campaigns, and training of health professionals on all levels.

By contrast, in the United States, bats were responsible for $70 \%$ of 125 human rabies cases recorded from 1960 to $2018^{24}$. Cases transmitted by hematophagous bats have also appeared in rural Ceará since 1985. In three cases that occurred in 1983, 1985, and 1993, it was not possible to identify the aggressor animal. Probably, the animal involved was the hematophagous bat Desmodus rotundus. It can happen that the victims are used as a food source for these animals and, due to the size of the wound and the subtlety of the animals' attack, they often go unnoticed ${ }^{25}$. However, it was not possible to confirm the type of viral variant present, as we do not yet have evidence for this in Brazil. From 1996 to 2001, the identification of the rabies viral variant was carried out only for research purposes, and since 2002, antigenic identification with monoclonal antibodies was implemented at the Pasteur Institute in São Paulo ${ }^{36}$.

Only one case was transmitted by a cat in 1979, in Fortaleza, the capital city of Ceará. To date, there have been no records of rabies cases with cats as transmitters in the state's database. Although canine rabies is under control in Ceará, surveillance in domestic species still requires attention, as treatment for disease transmitted through dogs accounts for more than $70 \%$ of post-exposure treatments in the state, after attacking humans ${ }^{26,27}$. Another concerning issue is the maintenance of the rabies virus by wild animals such as bats, crab-eating fox (Cerdocyon thous), marmosets (Callithrix jacchus), and raccoons (Procyon cancrivorus), as confirmed by the state laboratory ${ }^{26}$, which pose an imminent risk of transfer from wild to domestic species and secondary transmission to humans (bat-cat/dog-human) ${ }^{28}$. In Brazil, no immunization strategy is available against rabies for wild animal species, and the program relies on passive surveillance through viral monitoring of wild mammals found dead on the highways ${ }^{4}$.

Only $22 \%$ of victims had sought medical care after exposure. There is still a need for actions to alert the population of Ceará on the main aspects of rabies, especially on prevention, and the awareness that post-exposure prophylaxis is the only form of prevention after being attacked by a diseased animal ${ }^{15}$. 
In other settings, limited access to the health care system is another key factor. For example, in South Africa, the main reason for not initiating post-exposure prophylaxis was the lack of health professionals ${ }^{18}$. In Ceará, the professionals treated patients but did not prescribe a dose of vaccine, probably because they were unaware of the human anti-rabies treatment protocol available on the Ministry of Health website, and the established post-exposure prophylaxis guidelines ${ }^{29}$. According to the human anti-rabies prophylaxis protocol of the Brazilian Ministry of Health, post-exposure prophylaxis is indicated after aggression by wild animals and domestic animals roaming freely, or without the possibility of observation ${ }^{29}$. Postexposure prophylaxis is available free of charge within the nationwide Unified Health System (Sistema Único de Saúde).

Another Brazilian study on 82 cases of human rabies transmitted by wild animals, mostly bats, reported that post-exposure prophylaxis was not prescribed for $72 \%$ of patients $\mathrm{s}^{30}$. This is considered a major failure in health services because it is essential that professionals on the frontline of rabies surveillance have adequate knowledge and are aware of the risk of transmission, especially by wild animals. In 2020, in the northeastern Brazilian state of Paraíba, a woman was bitten on the hand by a wild canid, contracted rabies, and died. On the day she was attacked, she sought health services, but no recommendation for post-exposure prophylaxis was given by the health professional ${ }^{31}$. Human cases still occur and are related to the lack of awareness of the population followed by inadequate healthcareseeking behavior, and by the failure of the health care system, leading to missed opportunities to save lives ${ }^{14,34}$. There is a clear need to update professionals working in rabies surveillance and treatment.

Several patients abandoned post-exposure prophylaxis, compromising the body's immune response and favoring disease development. In Mozambique in 2014, similar observations were made, and many patients did not receive full treatment to develop the disease ${ }^{19}$. In other countries, such as India, a minority of rabies victims received complete post-exposure prophylaxis, mainly due to the absence of vaccine and antiserum ${ }^{19,20,32}$.

Even though canine rabies is controlled in Ceará, there is a high risk that dogs and cats might be contaminated by wild animals and then the virus transmission may restart to humans. To control rabies maintained and transmitted by dogs and humans with virus transmission by wild species, the state of Ceará performs surveillance actions in an integrated and continuous manner, in collaboration with different institutions.

The state develops strategies that consider the local situation and conditions, providing the availability of supplies in a timely manner to ensure a better response and the non-occurrence of human cases.

To increase effectiveness, rabies control requires a multidisciplinary, one-health approach. The disease is associated with all four determinant groups described by One Health as causing disease ${ }^{33}$ : First, as a zoonosis, animal health plays an important role; second, populational and social factors such as poverty, inadequate living conditions, access to education, and human behavior are interlinked with the disease; third, the health care system, surveillance, professional training, and access to health care are pivotal factors; and finally, environment and climate change can be considered as ad- ditional driving factors for the dynamics of virus transmission. As shown by our group previously and exemplified by the last 6 cases that occurred in Ceará ${ }^{34}$, intensified operational and implementation research efforts at this last mile are needed to identify bottlenecks in the control programs that are specific for each setting.

This study had several limitations. We analyzed the secondary data, and some medical charts did not provide complete information. In addition, it was possible to include only $37 \%$ of registered rabies cases during the study period because the other charts could not be encountered in the archive. The information contained in the oldest medical records, such as data of type of exposure, lesion location, initial diagnosis, and origin of the attacking animal, was not complete. Despite these limitations, this study provides information of great relevance to human rabies.

It can be concluded that most human rabies cases in Ceará occurred due to the failure to seek assistance and due to the failure of the health care system to initiate and complete early post-exposure prophylaxis. There is a need for specific information and education campaigns focusing on the sylvatic rabies cycle and prevention measures. Health professionals need refresher training courses on the signs and symptoms of rabies and on the specific epidemiologic features of the disease in Brazil.

\section{ACKNOWLEDGMENTS}

We thank the professionals of Hospital São José de Fortaleza for contributing to the collection of data from medical records. JH is class 1 research fellow from the Brazilian Research Council (Conselho Nacional de Desenvolvimento Científico e Tecnológico - CNPq).

\section{AUTHORS' CONTRIBUTION}

Duarte NFH: Conception and design of the study, Acquisition of data, Analysis and interpretation of data, Drafting the article, Final approval of the version to be submitted; Heukelbach J, Alencar CH: Conception and design of the study, Analysis and interpretation of data, Drafting the article, Final approval of the version to be submitted; Pires Neto RJ, Viana VF, Feijão LX: Conception and design of the study, Revision of article draft, Final approval of the version to be submitted.

\section{CONFLICT OF INTEREST}

The authors declared having no conflicts of interest.

\section{FINANCIAL SUPPORT}

No financial support was provided for this study.

\section{ORCID}

Naylê Francelino Holanda Duarte: 0000-0003-3230-6058

Roberto da Justa Pires Neto: 0000-0003-0291-9523

Victoria Forte Viana: 0000-0003-4087-2818

Levi Ximenes Feijão: 0000-0002-1850-0383

Carlos Henrique Alencar: 0000-0003-2967-532X

Jorg Heukelbach: 0000-0002-7845-5510 


\section{REFERENCES}

1. World Health Organization (WHO). OPAS comemora redução de novos casos de raiva nas Américas e pede esforço contínuo para alcançar a eliminação até 2022 [Internet]. Geneva: WHO; 2020 [cited 2020 Jan. 10]. Available from: https://www.paho.org/pt/noticias/25-9-2020-opascomemora-reducao-novos-casos-raiva-nas-americas-e-pede-esforcocontinuo.

2. Hampson K, Coudeville L, Lembo T, Sambo M, Kieffer A, Attlan M, et al. Estimating the Global Burden of Endemic Canine Rabies. PLoS Negl Trop Dis. 2015 2015;9(4):e0003709. Available from: https://doi. org/10.1371/journal.pntd.0003709.

3. Organização Panamericana da Saúde (OPAS). Organização Mundial de Saúde (OMS). Raiva [Internet]. Duque de Caxias: OPAS; 2021 [cited 2021 Jan 4]. Available from: https://www.paho.org/panaftosa/index. php?option=com_content $\&$ view=article\&id=509:rabia\&Itemid= 181 .

4. Ministério da Saúde (MS). Secretaria de Vigilância em Saúde. Sistema Nacional de Vigilância em Saúde. Raiva: o que é, causas, sintomas, tratamento, diagnóstico e prevenção [Internet]. Brasília: Ministério da Saúde; 2020 [cited 2020 jul 4]. Available from: http://www.saude.gov.br/ saude-de-a-z/raiva/\#epidemiologia.

5. Favoretto SR, de Mattos CC, de Mattos CA, Campos AC, Sacramento DR, Durigon EL. The emergence of wildlife species as a source of human rabies infection in Brazil. Epidemiol Infect. 2013;141(7):1552-61. Available from: https://doi.org/10.1017/S0950268813000198.

6. Schneider MC, Romijn PC, Uieda W, Tamayo H, da Silva DF, Belotto A, et al. Rabies transmitted by vampire bats to humans: An emerging zoonotic disease in Latin America? Rev Panam Salud Publica. 2009;25(3):260-9. Available from: https://doi.org/10.1590/s1020-49892009000300010.

7. Duarte NFH, Pires Neto RJ, Viana VF, Feijão LX, Abreu KG, Melo IMLA, et al. Epidemiologia da raiva humana no estado do Ceará, 19702019. Epidemiol Serv Saude. 2021;20:e2020354. Available from: https:// doi.org/10.1590/s1679-49742021000100010.

8. Duarte NFH, Alencar CH, Cavalcante KKS, Correia FGS, Romijn $\mathrm{PC}$, Araujo DB. Increased detection of rabies virus in bats in Ceará State (Northeast Brazil) after implementation of a passive surveillance programme. Zoonoses Public Health [Internet]. 2020 dez [cited 2019 Dec 20];66(8):1-7. Available in: https://onlinelibrary.wiley.com/doi/ abs/10.1111/zph.12670. doi: https://doi.org/10.1111/zph.12670.

9. Favoretto SR, de Mattos CC, de Morais NB, Carrieri ML, Rolim BN, Silva LM, et al. Rabies virus maintained by dogs in humans and terrestrial wildlife, Ceará State, Brazil. Emerg Infect Dis. 2006;12(12):1978-81. Available from: https://doi.org/10.3201/eid1212.060429.

10. Duarte NFH, Melo IMLA, Franco ICF, Oliveira RP, Duarte BH, Garcia MHO, et al. Caracterização da raiva humana no Estado do Ceará, Brasil, 1990 a 2016. In: Anais do $10^{\circ}$ Congresso Brasileiro de Epidemiologia [Internet]; 2017; Campinas, Brasil. Campinas: Galoá; 2017 [cited 2020 mar 30]. Available from: https://proceedings.science/epi/trabalhos/raiva-humana-transmitida-pormorcego-hematofago-ceara-2016-acoes-de-prevencao-e-controle?lang=pt-br.

11. Duarte NFH, Moura FBP, Lima FMG, Sousa TC, Franco ICF, Melo IMA, et al. Raiva humana transmitida por morcego hematófago Ceará, 2016: ações de prevenção e controle. In: Anais do $10^{\circ}$ Congresso Brasileiro de Epidemiologia [Internet]. 2017; Campinas, Brasil. Campinas: Galoá; 2017 [cited 2020 mar 30]. Available from: https://proceedings.science/ epi/trabalhos/raiva-humana-transmitida-pormorcego-hematofago-ceara2016-acoes-de-prevencao-e-controle?lang=pt-br.

12. Singh R, Singh KP, Cherian S, Saminathan M, Kapoor S, Manjunatha Reddy GB, et al. Rabies - epidemiology, pathogenesis, public health concerns and advances in diagnosis and control: a comprehensive review. Vet Q. 2017;37(1):212-51. Available from: https://doi.org/10.1080/0165 2176.2017.1343516.
13. Silva Mendes W, Silva AAM, Neiva RF, Costa NM, Assis MS, Vidigal PMO, et al. An outbreak of bat-transmitted human rabies in a village in the Brazilian Amazon. Rev Saude Publica. 2009;43(6):1075-7. Available from: https://doi.org/10.1590/s0034-89102009005000073.

14. Vargas A, Romano APM. Merchán-Hamann E. Raiva humana no Brasil: estudo descritivo, 2000-2017. Epidemiol Serv Saude. 2019;28(2):e2018275. Available from: https://doi.org/10.5123/s167949742019000200001.

15. Ministério da Saúde (MS), Secretaria de Vigilância em Saúde. Coordenação-Geral de Desenvolvimento da Epidemiologia em Serviços. Guia de vigilância em saúde: volume único. $3^{\mathrm{a}}$ ed. Brasília: MS; 2019. [cited 2021 jul 03]. Available from: https://portalarquivos2.saude.gov.br/ images/pdf/2019/junho/25/guia-vigilancia-saude-volume-unico-3ed.pdf.

16. Gomes AP, Esperidião-Antonio V, Mendonça BG, Leite HP, Henriques D, Santana LA. Raiva Humana. Rev Bras Clin Med. 2012;10(4):334-40. [cited 2021 jul 03]. Available from: http://www.sbcm.org.br/revistas/ RBCM/RBCM-2012-04.pdf\#page=69.

17. Willoughby, RE. Milwaukee protocol and human rabies outcomes: oral presentations human rabies and prophylaxis. Moderators: Alan Jackson and Cristián Biscayart. In: Anais do $29^{\text {th }}$ Rabies in the Americas; 2018; Buenos Aires, Argentina. Buenos Aires: RIBA; 2018. [cited 2021 jul 03]. Available from http://www.ritaconference.org/documentos/Programa-RITA-2018.pdf.

18. Weyer J, Szmyd-Potapczuk AV, Blumberg LH, Leman PA, Markotter W, Swanepoel R, et al. Epidemiology of human rabies in South Africa, 1983-2007. Virus Res. 2011;155(1):283-90. Available from: https://doi. org/10.1016/j.virusres.2010.10.023.

19. Salomão C, Nacima A, Cuamba L, Gujral L, Amiel O, Baltazar C, et al. Epidemiology, clinical features and risk factors for human rabies and animal bites during an outbreak of rabies in Maputo and Matola cities, Mozambique, 2014: Implications for public health interventions for rabies control. PLoS Negl Trop Dis. 2017;11(7):e0005787. Available from: https://doi.org/10.1371/journal.pntd.0005787.

20. Hossain M, Ahmed K, Bulbul T, Hossain S, Rahman A, Biswas MN, et al. Human rabies in rural Bangladesh. Epidemiol Infect. 2012;140(11):196471. Available from: https://doi.org/10.1017/S095026881100272X.

21. Meslin FX, Briggs DJ. Eliminating canine rabies, the principal source of human infection: What will it take? Antiviral Res. 2013;98(2):291-6. Available from: https://doi.org/10.1016/j.antiviral.2013.03.011.

22. Fooks AR, Banyard AC, Horton DL, Johnson N, McElhinney LM, Jackson AC. Current status of rabies and prospects for elimination. Lancet. 2014;384(9951):1389-99. Available from: https://doi.org/10.1016/ S0140-6736(13)62707-5.

23. Schneider MC, Almeida GA, Souza LM, Morares NB, Diaz RC. Controle da raiva no Brasil de 1980 a 1990. Rev Saude Publica. 1996;30(2):196-203. Available from: https://doi.org/10.1590/S0034-89101996000200012.

24. Ma X, Monroe BP, Cleaton JM, Orciari LA, Gigante CM, Kirby JD, et al. Rabies surveillance in the United States during 2018. J Am Vet Med Assoc. 2020;256(2):195-208. Available from: https://doi.org/10.2460/javma.256.2.195.

25. De Serres G, Dallaire F, Côte M, Skowronski DM. Bat rabies in the United States and Canada from 1950 through 2007: Human cases with and without bat contact. Clin Infect Dis. 2008;46(9):1329-37. Available from: https://doi.org/10.1086/586745.

26. Cordeiro RA, Duarte NF, Rolim BN, Soares Júnior FA, Franco IC, Ferrer LL, et al. The importance of wild canids in the epidemiology of rabies in Northeast Brazil: A retrospective study. Zoonoses Public Health. 2016;63(6):486-93. Available from: https://doi.org/10.1111/zph.12253.

27. Cavalcante KK, Florêncio $\mathrm{CM}$, Alencar $\mathrm{CH}$. Profilaxia antirrábica humana pós-exposição: características dos atendimentos no estado do Ceará, 2007-2015. J Health Biol Sci. 2017;5(4):337-45. Available from: http://dx.doi.org/10.12662/2317-3076jhbs.v5i4.1348.p337-345.2017. 
28. Kotait I, Carrieri ML, Carnieli Júnior P, Castilho JG, Oliveira RN, Macedo CI, et al. Reservatórios silvestres do vírus da raiva: um desafio para a saúde pública. BEPA, Bol epidemiol paul. 2007;4(40):2-8. [cited 2021 jul 03]. Available from: http://periodicos.ses.sp.bvs.br/pdf/bepa/v4n40/ v4n40a01.pdf.

29. Departamento de Vigilância Epidemiológica. Protocolo para tratamento de raiva humana no Brasil. Epidemiol Serv Saude. 2009;18(4):385-94. Available from: http://dx.doi.org/10.5123/S1679-49742009000400008.

30. Rocha SM, De Oliveira SV, Heinemann MB, Gonçalves VSP. Epidemiological profile of wild rabies in Brazil (2002-2012). Transbound Emerg Dis. 2017;64(2):624-633. Available from: https://doi.org/10.1111/ tbed.12428.

31. Ministério da Saúde (MS), Secretaria de Vigilância em Saúde (SVS). Síndrome Inflamatória Multissistêmica Pediátrica (SIM-P), temporalmente associada à COVID-19. Boletim Epidemiológico 35 Volume 51 | Ago. 2020. [cited 2021 jul 03]. Available from: https://antigo.saude.gov.br/images/ pdf/2020/September/04/Boletim-epidemiologico-SVS-35-editado.pdf.

32. Sudarshan MK, Madhusudana SN, Mahendra BJ, Rao NS, Ashwath Narayana DH, Abdul Rahman S, et al. Assessing the burden of human rabies in India: results of a national multi-center epidemiological survey. Int J Infect Dis. 2007;11(1):29-35. Available from: https://doi. org/10.1016/j.ijid.2005.10.007.

33. Heukelbach J. One health \& implementation research: Improving health for all. One Health Implement Res 2021;1:1-3. Available from: http:// dx.doi.org/10.20517/ohir.2020.01.

34. Duarte NFH, Alencar CH, Pires Neto RJ, Moreno JO, Araújo Melo IML, Duarte BH, Heukelbach J. Integration of Human Rabies Surveillance and Preventive Measures in the State of Ceará, Northeast Brazil. One Health Implement Res. 2021;1;17-30. Available from: https://dx.doi. org/10.20517/ohir.2021.02.

35. Favoretto SR, de Mattos CC, Morais NB, Alves Araújo FA, de Mattos CA. Rabies in marmosets (Callithrix jacchus), Ceará, Brazil. Emerg Infect Dis. 2001;7(6):1062-5. Available from: https://doi.org/10.3201/ eid0706.010630.

36. Favoretto SR, Carrieri ML, Cunha EMS, Aguiar EAC, Silva LHQ, Sodré MM, et al. Antigenic typing of brazilian rabies virus samples isolated from animals and humans, 1989-2000. Rev Inst Med Trop S Paulo. [Internet]. 2002 Apr [cited 2021 May 09];44(2):91-5. Available from: https:/doi.org/10.1590/S0036-46652002000200007. 